NEW LITERARIA-

An International Journal of Interdisciplinary Studies in Humanities

Volume 3, No. 1, January-February, 2022, PP. 61-71

ISSN: 2582-7375

DOI: https://dx.doi.org/10.48189/nl.2022.v03i1.007

www.newliteraria.com

\title{
Re-Imagining Sita in Chitra Banerjee Divakaruni's The Forest of Enchantments: A Spiritual Ecofeminist Reading
}

\author{
Gheeta Chandran, Foong Soon Seng \& Raphael Thoo Yi Xian
}

\begin{abstract}
The Forest of Enchantments (2019) by Chitra Banerjee Divakaruni narrates the epic Ramayana from Sita's voice, one of the prominent female characters in Indian Literature. Through myriads of Sita, the text focuses not just on her spiritual being but her identity as a woman. This novel warrants a study as it explores Sita's immense strength and humanises her journey amidst the unknown and mysterious forest. The study intends to examine the relationship between Sita and the nature, because the forest in this tale is an imperative source of empowerment. Sita draws her strength in her painful solidarity and exile in the forest. It provides her voice, wisdom and agency to concede that each individual has their own insights of dharma, Sita argues and challenges the stark dichotomy between good and bad, instating that perspective is something that differs. In the line the cultural ecofeminist current that initially dominated justified women's interest in the preservation or well-being of the environment in terms of their inherent caring or nurturing nature and their common subjection to patriarchal systems, the paper intends to investigate relationship between Sita and environment. The paper also aims to study the association of a woman with nature that is embraced as a source of power and the ways in which Sita's relationship to the environment empowers her to speak for all the other women of Ramayana, even those outcasts and undermined, creating a more modern and liberal version of women in Indian mythology. Thus, this is an important study in current time as it aims to explore Sita with agency in the different stages of the narrative.
\end{abstract}

Keywords: Ecofeminism, Spirituality, Women Empowerment, Oppression, Indian Literature, Mythology.

\section{Introduction}

The Forest of Enchantments (2019) by the renowned Chitra Banerjee Divakaruni is a retelling of the much discussed and studied Hindu epic, the Ramayana but imagined in Sita's own voice. Sita is highly regarded as one of the most influential and subject of interests for many literary and feminist studies. This is mainly due the perplexment over her banishment, which gives birth to Divakaruni's version of the epic that aims to demystifies Sita and other ostracised women in the Ramayana. She attempts to clear the misconceptions about these women by giving them a chance to speak out and voice their side of the story. Despite being one of the affluential characters in Ramayana, Sita's perspective about her exile to the forest is not explored in the epic. Therefore, Divakurani empowers Sita through her retelling; "Write our story too. For always we've been pushed into corners, trivialized, misunderstood, blamed, forgotten-or maligned and used as cautionary tales" (Divakaruni, 2019, p. 4). The Forest of 
Enchantments (2019) dwells in the notion of women's struggle, honour and sense of duty to self and society that are still very much relevant and common in current times.

Sita's story has been told in her own words in The Forest of Enchantments (2019). She shares her pleasures, sorrows, and perseverance, as well as her view of love. Furthermore, the story depicts Sita's journey from earth to heaven and back, as well as her love and connection with environment and nature. It portrays Sita's ability to heal both nature and herself. The narrative also shows how great warriors' prejudice led to the exploitation of both nature and women as a result of their misogyny. The book examines the relationship between women's exploitation and nature, as well as the conflict between civilization, nature, man and woman. In addition to that, through myriads of Sita, the text focuses not just on her spiritual being but her identity as a woman. This paper intends to examine the relationship between Sita and the nature, because the forest in this tale is an imperative source of empowerment. Sita draws her strength in her painful solidarity and exile in the forest. It provides her voice, wisdom and agency to concede that each individual has their own insights of dharma, Sita argues and challenges the stark dichotomy between good and bad, instating that perspective is something that differs.

In the line the ecofeminist spirituality current that justified women's interest in the preservation or well-being of the environment in terms of their inherent caring or nurturing nature and their common subjection to patriarchal systems, the paper intends to investigate relationship between Sita and environment. The paper also aims to study the association of woman with nature that is embraced as a source of power and the ways in which Sita's relationship to the environment empowers her to speak for all the other women of Ramayana, even those outcasts and undermined, creating a more modern and liberal version of women in Indian mythology. Thus, this is an important study in current time as it aims to explore Sita with agency in the different stages of the narrative.

\section{Revisiting Mythologies}

Once again, we are faced with spiritual psychologists of the twentieth century, who saw the search for myths as an important factor in creating meaning in life. Divakaruni is an exemplary writer in this quest, she explores myths to uncover the many hidden and ignored truths that give many perspectives and great meaning to life. The policy of intentionally creating myths to manipulate modern culture has been consistently used in recent history. For example, Romantic writers like Emerson, Thoreau, and Whitman aimed to design a particular myth for America's young nation (Feldman \& Richardson, 1682), and fascists like Benito Mussolini and Alfred Rosenberg championed move people to use mythological themes. Arvidsson (1999) asserts:

Myths were in reality poetic exegeses of the laws of nature and of behavior: allegoric interpretation. Or else myths were distorted historical reports in which the heroes had been attributed divinity: euhemeristic interpretation. In both cases the interpretation meant that behind the apparent childish foolishness of the myths a hidden, distorted truth could be detected. Thus myths-behind the overt stupidities and repulsiveness did, if properly interpreted, display something rational (Arvidsson, 1999, p. 329).

When life is often stripped of its spirituality, meaning, and grandeur by a rigid and scientific mindset, myth can break this monotony through the stimulation of the imagination. spread ancient wisdom. However, mythology in the early 19th century was first seen as a lifeaffirming genre within trendy romanticism and contradicted the word everyday meaning as a false story. True life, therefore, is only possible when myth overwhelms symbols. On the same 
line, Vayu Naidu (2012) asserts that retelling of mythologies induces cultural memory as "the function of memory as a metaphor for remembering a dismembered story because it is told to us infrequently and in parts, and for experiencing culture through its epic characters" (Naidu, 2012, p. 170). Sita through many modern stories remains to challenge and question our beliefs about her journey and personality. Thus, story that gives us new perspectives can and should be allowed to understand what is valued across cultures, despite different traditions. Naidu (2012) asserts on Sita,

In one sense, Sita is an inheritance and a legacy for many women, not an imposition. While reimagining Sita and her story, it was an enriching journey to enter into the idea that Sita is exiled and adopted-both literally and metaphorically-by the country endorsed as 'marriage'. In our times, endurance in women is precariously interpreted as the attribute of a victim, but Sita has resourcefulness, fortitude, cheerfulness and an ocean of love despite being placed in circumstances not of her choosing as an orphan and an exile (Naidu, 2012, p. 182).

The country is "built upon an age-old belief the citizens of Mithila hold: no woman is strong enough-or wise enough-to guide them" (Divakaruni, 2019, p. 14). However, Sita's fate is not that of an ordinary princess, and even Shiva's Haradhanu, a sacred bow bestowed to protect Sita, sometimes reminds her that "I [Sita] was no ordinary person but one with a complicated destiny. My great sacrifice, it [the bow] indicated, would save the world" (Divakaruni, 2019, p. 27). Paula Richman (2008) highlights, "Valmiki's Ramayana tends to affirm the values of the social order of his day, thus helping to uphold institutionalized power" (Richman \, 2008, p. 9). Similarly, Bose and Bose (2013) contend that the different versions of Ramayana generally "centred on the glorification of Rama and his conquering arms". They further specify that "sympathy for Sita pervades these mournful narratives, often quite short and focused on domestic relationships rather than heroic deeds" (Bose, 2012, p. 4).

The Forest of Enchantments (2019) narrates the unconventional way Sita grows up, she is perceived to be unique and unlike other Mithila princesses. Her mother pointed out that "I sense that your future's going to be different from that of most princesses" (Divakaruni, 2019, p. 9). Sita is an atypical princess who dares to say what she thinks and defies convention with her wits and sharp tongue. For example, in a Swayamvara, Sita proves to Ram that she is more than just a girl. Her impulsiveness prompted her to speak up. Like her mother, her strong personality is illustrated in the following excerpt: "But deep inside me someone-was it the goddess?- said, It's important to speak your mind to the man you're going to marry. What kind of relationship would you have if you couldn't do that?" (Divakaruni, 2019, p. 36). However, Sita's unconventional qualities are not "the ones society values most in a woman" (Divakaruni, 2019, p. 46).

\section{Ecofeminist Spirituality}

Ecofeminism is a branch of feminism that sees environmentalism and the relationship between women and the earth, as foundational to its analysis and practice. Ecofeminist thinkers draw on the concept of gender to analyse the relationships between human and the natural world (Mac Gregor \& Sherlilyn, 2004). The term ecofeminism is often said to have been coined in the work of the French feminist Françoise d'Eaubonne (1974). However, some ecologists (Gaard 1998; Salleh 1991) argue that, as a term, "ecofeminism" emerged during the 1970s as a respond to many development activities. The origins of ecofeminism theory can also be seen in earlier feminists, as explained by Val Plumwood (1996):

From early and liberal feminism, it takes the impulse to integrate women fully as part of human culture and from socialist feminism, it draws an understanding of the processes and structures of power and domination. From radical feminism, it takes the 
critique of the masculinity of dominant culture and the aspiration to replace it, to affirm what has been denigrated (Plumwood, 1996, p. 13).

In 1991, Karen Warren edited an edition of Hypatia devoted entirely to ecofeminism, which was later developed and republished under the title Ecofeminist Philosophy. This anthology is revolutionary, for Warren has united a diverse set of voices in it, not in such an ecofeminist background, but in a view of reality on the ground, so to speak, in relation to ecofeminism. Activists are not held back by inadequate theoretical bases because the lack of a full theoretical account has become more of a tool for conservative policymakers to avoid implementing change. This is because Warren's ecofeminist theory provides the theoretical and analytical basis for their direct action. In addition, her work assures work promises solidarity with fighters and their ability to integrate their goals and justifications undermines and counters the image of the powerful extremist activists revered across the globe in contemporary media. Therefore, it shares with them a global social vision and it finds its roots in ecofeminist spiritualism.

Warren's advocacy for ecofeminist spirituality is strategic in her proposals for wellbeing and alternative spaces. Spirituality is related to power, especially the power to move from "unhealthy, life-denying systems and relationships to healthy, life-affirming" (Warren, 2000, p. 200) ones, it creates a space to draw inner strength and for empowerment without involving violence. In 1993, Warren argued that ecofeminist spirituality provided a place to heal the wounds inflicted on women and nature by patriarchy. In 2000, she further asserts that ecofeminist spirituality is a tool for surviving and overcoming patriarchy because ecofeminist spirituality has a potential "to intervene in and creatively change patriarchal (and other) systems of oppression” (Warren 2000, p. 195).

It is undeniable this framework is criticised and discredited among other feminists, Simone de Beauvoir, to begin with who argues that the interconnection of women and nature is a "renewed attempt to pin women down to their traditional role" (de Beauvoir 1984, p. 103). To this Warren asserts that spirituality should not be reduced to a degrading mind or emotion dichotomy, but rather is a way to show that emotions can be inferred and have strong relationships with valid beliefs. Thus, she coined a concept called "emotional intelligence" in Ecofeminist Philosophy which is part of Warren's prudent ethic, which relies on its ability to care, situated rather than transcendent. Therefore Warren (2000) applies an analogy to explain her ethics. Different ethical principles are like fruit in a bowl: "It is not that one fruit is better than the others in some abstract sense. It is just that one fruit (or several fruits) may be better than others in the circumstances" (Warren, 2000, p. 108). Ecofeminist spiritualities provide an understanding of self and human being that encourage the sense of "daring to care" (Warren, 2000, p. 212) requisite for such care-sensitive ethics to get off the ground. Therefore, the spirituality of eco-feminists may be "often clearly earth-based" (Warren, 2000, p. 130), but this does not reinforce the detrimental identity of women with nature, but it reminds us that the distinction between "human" and "nature" is a false dichotomy. As such, spirituality does not function to lock the woman into the role of caretaker, but rather than limiting the woman to nature, this promises a conceptual framework in which it includes the men.

\section{Reimagining Sita; Spiritually Empowered}

Sita in Ramayana is revered for her dedication to her dharma (duty) as wife and mother and for the sacrifices she made to achieve this vocation. She is considered as a symbol of femininity and is an ideal to imitate for other women. Though she is a Goddess herself, the incarnation of Goddess Lakshmi, Sita is often view as an extension of Lord Ram, but not an aspired individual 
with vision. Sita is often seen as the epitome of perseverance. It is often equated with submissiveness, yielding and gentleness and is cited as an example of the socialization of girls in Indian culture. A woman's devotion to her husband, under all circumstances, is preserved as the incarnation of righteous conservatism. Divakurani in The Forest of Enchantments (2019) maintains the core identity of Sita, which is her ability to endure inexplicable and innumerable pain. However, in this text the notion of endurance is not seen as weakness but it is associated with the strength. During her contemplation in the forest, Sita dreams about Sunaina, Ahalya, Mandodari, Sarama, Kalkeyi, Tara and even Surpanakha who advises her to endure. In the dream, they suggest Sita to endure as we do. Endure your challenges" (Divakaruni, 2019, p. 322). As Sita contemplates meaningfully over the word 'endurance', she understands the true meaning of it, "It meant taking the challenges thrown at us and dealing with them as intelligently as we knew until we grew stronger than them" (Divakaruni, 2019, p. 322).

Therefore, the text propagates a new sense of empowerment through endurance that ultimately leads women to challenge the obstacles and strive in triumph. Another imperative incident in the novel that support this notion is when Sita decides to accompany Ram to the forest. Ram objects, by undermining her capability as a woman; "What folly is this? You can't possibly come with me. You're a woman" (Divakaruni, 2019, p. 111). Sita refrains from speaking out but she wanted to counter Ram's belief "not all women are weak and helpless like you think. For all you know, I might be of help to you" (Divakaruni, 2019, p. 111). In the forest their meeting with Ahalya, allows us to see the silent suffering of another woman from different angle from Divakaruni's Sita. Ahalya, is turned into stone by her husband for not fault of hers. Ahalya is saved by Ram and according to Sage Gautam, she has taken "a vow of silence" (Divakaruni 131). Sita questions Ahalya because she's perplexed with the injustice prevailed in the whole situation and Ahalya replies:

I tortured myself with these same thoughts many times as I lay stone-bound. Yes, that was part of the curse-that I should feel every moment of my internment... When you put your hand in the fire, knowingly or unknowingly, do you not get burned? Such is the ancient law of the universe. Of karma and its fruit. The idea of motive is irrelevant to it (Divakaruni, 2019, p. 134).

Sita is shocked by Ahalya's reply as she always believes that "motive was more important than action, more even than destiny" (Divakaruni, 2019, p. 134). Sita's prophetic dream about Ahalya's punishment allows her to see things from another perspective where Ahalya's vow of silence serves as a reminder that punishes Gautam for what he has done. The lesson Sita learns from her prophetic dream is "once mistrust has wounded it mortally, love can't be fully healed again" (Divakaruni, 2019, 136) and this foreshadows her own fate in the later part of the novel.

The novel also portrays the intricate details about Sita's connection with the nature. Though Ramayana associates Sita with nature, Divakurani provides the intimate details and thoughts that predominate in Sita in relation to her bond and equation with the nature and all that is comprised within it. This can be explained by two examples of her determination and independent action. She chooses to live amidst the hardships of the forest, leaving her royal extravagant life, and of her own free will, decides to join the Mother Earth when asked to prove her chastity for the second time. This proves that nature empowers her as she perceives the forest as a form of "healing green canopies" (Divakaruni, 2019, p. 352). Sita claims that "I'm Sita, the forest dweller, Sita, daughter of earth. And yes, Sita, daughter of fire as well" (Divakaruni, 2019, p. 352).

Aligning to the ecofeminist spiritualities, Sita's association with the forest "express faith in a life-affirming power of presence (i.e. energy, force, being, deity or deities, God or Goddess) (Warren, 2000, p. 198). Since young, Sita has been drawn to the forest. She recalls; 
"Because what called to me most powerfully were the forests that I could see from the palace turrets...No one in my family felt the way I did about forests" (Divakaruni, 2019, pp. 7-8). Sita claims that "My strange gift with plants was a mystery to me. Perhaps it was because, like them, I was earth-born. Maybe for some reason, when I touched a plant, I knew its healing properties" (Divakaruni, 2019, p. 7). Naidu (2012) asserts to this idea by saying, "we rarely see her in the safe interiors of palaces for long; wilderness and abandon are where she triumphs" (Naidu, 2012, p. 174). Sita states that "perhaps I'd be able to think more clearly under its majestic trees'” (Divakaruni, 2019, p. 321).

Sita, is the symbolic representation of nature in The Forest of Enchantment (2019). She is said to be born from Earth when her father, king Janaka found her while ploughing the ground. Her childhood is depicted as:

My strange gift with plants was a mystery to me. Perhaps it was because, like them, I was earth-born. Maybe for the same reason, when I touched a plant, I knew its healing properties... (Divakaruni, 2019, p. 7)

Because she could cure many people with her knowledge about the medicinal properties of her herbs, she was often called a "Goddess" by the people of her kingdom. From a very early time she was fascinated by the forest and the people that lived there. She wanted to visit the forest but "It wasn't something that women did" (Divakaruni, 2019, p. 8)

To further prove that Divakurani's Sita is indeed an embodiment of ecofeminist spirituality, she is depicted as someone who comprehends the ways in which women and nature are dominated, abused, and manipulated by men for their own benefits and in the name of betterment for the civilisation. Being deemed as the reincarnation of Lakshmi, she says "they [citizen of Ayodhya] called me, food giver, queen of flowers, removers of sorrows" (Divakaruni, 2019, p. 288). "The only thing distressing me [Sita] was the callous behaviour of the soldiers. Could he [Ram] order them not to harm the trees?... Ram's brows drew together in surprise. Clearly, he'd never considered that plants feel pain as we do" (Divakaruni, 2019, p. 56). Ram replies that "You are tender-hearted, my dear. I can't fault that. It's right and necessary that women should be so" (Divakaruni, 2019, p. 56). Sita could not comprehend that and thought "Wasn't he responsible for the animals and birds and trees in his realm, as well as the people? (Divakaruni, 2019, p. 56).

In her exile, Sita didn't find it too difficult to make herself home and reconnects with the nature. She insists that:

Here in Panchabati I saw brilliant sunsets spreading like a smile across the sky and molten-silver moonrises. I saw stars glimmering like shy eyes from behind veils of cloud. I saw birds and beasts, multi-hued, multi-pelted, so different from the creatures I'd known that I was struck with awe. The plants here were particularly attuned to me. Bushes would pull in their sharp thorns and burst into flower when I watered them or loosened the earth around their roots (Divakaruni, 2019, p. 137).

Sita further proves this point by admitting "My favourite responsibility [as the Queen of Ayodhya], the garden palace...The entire side of the grounds that lay behind the palace I'd made into a little forest" (Divakaruni, 2019, p. 303). Although she turns her garden into a "little forest", she mentions that "but some days a strange dissatisfaction would come over me, a longing to go walking in a real forest, a wild, unpredictable forest, the kind that had been my 
home for so many years" (Divakaruni, 2019, p. 303). Sita's deep connection with the forest and the lives surrounding it is a clear evident that, unlike the popular belief the jungle is not a real of darkness and unknown for her. In fact, it is here she feels the most powerful and alive.

Sita's stand to protect and treat the nature and its habitants equally to human beings can be seen in her conflict with Ram and Lakshman during their journey to exile. The brothers have the mindset that the wilderness should be tamed and put under control, although it is them who are invading into the forest habitants' space much like today's concept of modernisation and deforestation. For example, in one part of the novel, a sage explains to the brothers their ultimate purpose behind the exile as “........perhaps that's why destiny brought you to the forest; Gautam was saying. To get rid of them for good. To wipe out their unholy ways. To spread the light of civilization. You must promise me you'll try you best to do that." (Divakaruni, 2019, p. 135)

Failure to understand that every living thing has their right to live and prosper in their designated space is a prevalent problem in our social order be it then or now. The constant need of the patriarchal authority to dominate others' domains, gets the forest and its living under their subjugation. The drive to conquer the resources in the forest enables the patriarchy to invade the forest in the name of need, hunting and even civilisation.

The uncivilised method used to treat Surpanakha is also an example of this kind of apathetic attitude towards the different habitants, Ram and Lakshman fail to see beyond Surpanakha's origin and background, most importantly they fail to see her as a woman who did nothing but offer love. Both men could have handled the situation diligently without humiliating the woman.

Admittedly, the girl had gone beyond the norms of maidenly behavior, offering herself to a man she barely knew, but perhaps the rules of conduct were different for the asuras..... I gestured to her from behind Ram's back to leave with dignity before things went any further. (Divakaruni, 2019, p. 148)

She looked at my husband, her eyes full of disbelief that someone could do such a thing to her when all she'd offered him was love. (Divakaruni, 2019, p. 149)

Sita's concern over what happened is brushed off uncaringly by Ram and Lakshman, the brothers callously dismiss the matter by justifying that how Rakshashas are to be treated because they are threat to mankind and it's their duty to kill them whenever they are to see one. Ram further justified Lakshman's actions : “.... 'Infact', he continued, 'Lakshman was being kind to this one, sparing her life because she was a female.“" (Divakaruni, 2019, p. 151)

For Sita, it is undeniable that Surpanakha is treated unjustly and when her husband defends the act as a service to mankind, the sages particularly need peace and safety, she states:

I didn't argue further. I could see that the men wouldn't change their minds. Their belief in their superiority of their own ways was too deeply ingrained in them. But I wasn't satisfied. We were visitors to the forest which already had its own rules, its own rhythm, its own savage beauty . It belonged more to the Rakhshasas than to us. What right did we have to cause destruction to those who had been here long before we came? (Divakaruni, 2019, pp. 151-152)

Throughout the novel Sita does not only tries to save the nature, draw strength but also comfort and love from it. When she is under Ravan's captivity nature comforts as a Mother 
would a child. The flora and fauna empathise with her sorrow and pain ".... When I touched them I could feel their sympathy for me. If they were willing my touch cured them. And thus we grew to love each other. I was particularly fond of the Asoka tree under which I slept..." (Divakaruni, 2019, p. 187). When Sita is banished one more time to the forest, again the nature brings her a great sense of strength and power that enable her nurture and raise her sons to be "good human beings," as compared to the father who treats them cruelly. Sita declares that:

I am going to live for you [her babies]. I'm going to guard you with my last breath. I'm going to love you enough for mother and father both, so you feel no lack. I'm going to teach you everything you need to know to be good human beings, so that you'll never do to a woman what your father has done to me (Divakaruni, 2019, p. 317).

Ram comands Sita to return to the kingdom of Ayodhya, but Ram lets Sita down again by saying that she must pass the test of fire, also known as Yajna, to prove her innocence and purity. Sita, for all the adoration she has for her husband finds such order to be humiliating. Even both of her children, Lav and Kush are aware of their mother's suffering when they sing Sita's Sitayan instead of Valmiki's Ramayana.

They're [Lav and Kush] singing the pages I'd written in my lonely darkness, out of the need to give voice to all of us who were pushed to the edges. Misjudges, misunderstood. My truth, and the truth of the women whose lives touched mine for better or worse. Their laughter and tears, their triumph and suffering, their blessings and curses (Divakaruni, 2019, p. 354).

Feeling unbearable of such disgrace, Sita argues that:

Rage rises up in me until my whole body is scorched, for some kinds of burning don't require a fire. Not a word of love, not a word of apology for the sorrow he has caused me. Not a word about the unjust and cruel way in which he sent me away. He [Ram] hasn’t even called me by my name (Divakaruni, 2019, p. 355).

Sita refuses to succumb to such ignominy and declines the offer to live with Ram and her children in the Kingdom of Ayodhya. She argues that:

Because if I do what you demand, society will use my action forever after to judge other women. Even when they aren't guilty, the burden of proving their innocence will fall on them. And society will say, why not? Even Queen Sita went through it (Divakaruni, 2019, pp. 356-357).

I [Sita] call on my mother earth and father fire-for both have shaped me into the woman I am today-to come to my aid. O Mother, O Father, all my life I've suffered and endured and been wrongly accused. If I am indeed blameless of what gossipmongers whispered, give me a sign (Divakaruni, 2019, p. 357).

Sita seeking solace from Mother Earth as her final sanctuary exerts her strong protest the incessant betrayal and abandonment she faced in her life. And as Sita speaks; "a powerful energy" courses through her and "the earth cracks open with a deafening roar" (Divakaruni, 2019, p. 357). Sita is transforming back from a woman to a goddess. Though sometimes this act is interpreted as Mother Earth's protection to her daughter, the irony of the whole action is never lost as in another angle it is seen as being buried alive. In addition, entering the Mother Earth is also seen as an act of suicide, as suggested by Nabaneeta Dev Sen, that Sita's suicide is similar to women who choose to end their life due to abuse subjected to their bodies (Sen, 
2018, pp. 24-25). However, in his paper "When does Sita Cease to be Sita", Velcheru Narayana Rao (2004) emphasizes on the integral sense of empowerment and resistance that is evident in her decision:

In choosing to return to the earth, she has accomplished two things: she has proven her chastity and demonstrated her independence, as well. It is both a declaration of her integrity and a powerful indictment against a culture that suspects women. It is difficult not to interpret this as Sita's protest against the way she was treated by her people and by her husband (Bose, 2004, p. 226).

This final act of Sita's resistance to succumbing to submission will undoubtedly lead to empowerment for herself as well as for other women of the future who must resolutely resist such treatment. At this stage, Sita decides to end her others' control of her own life at once and realizes it is her time for self-actualization. It also leads to a personal journey of self-discovery as a woman caught up in radical and rebellious behaviour due to the carelessness of her husband and society. Moreover, in this final act of courage and strength, Sita proves that she is not at all weak and meek, as depicted in Vedic for ages.

\section{Conclusion}

Chitra Banerjee Divakaruni's The Forest of Enchantments (2019) provides a space for the misunderstood, misjudged and marginalised women in Ramayana, one of the renowned Indian epics of all time to speak and liberate themselves. This proves that fictions demand analysis and attention especially reinterpretations of myths. Hero in mythologies often is placed above all i.e., men, women and environment, he is superior and divine due to his position and power. In this novel, Divakaruni changes the one sided and blinded vision and shifted the gaze on the others, women and nature. Sita constantly reweaves and challenges the boundaries of social and moral norms in Sitayan. The multi-layered dimensions of Sita as an empowered woman all of which emerge at different stages of the narrative. Divakurani's attempt to shift the narration voice to Sita not only allow multiple perspectives and possibilities but also a step towards realist and ironic fiction from myth and epic. With semblance of truth and human interest is incorporated in mythologies and fantasy, readers would be allowed to be concerned about inconceivability of narratives by suspending their disbelief judgement. Conclusively, Sita's banishment from the oppressive setting that suppresses her voice and individuality to an enchanted journey in the forest, a realm of possibilities and freedom enables her to voice her side of the truth. This is an act of progress, a test that leads to individual empowerments. Through her voice of protest and resistance at various junctures of her life Sita has positioned herself as an equal thus empowered in the patriarchal society, in Divakurani's The Forest of Enchantments (2019).

\section{Reference}

Arvidsson, S. (1999). Aryan Mythology as Science and Ideology. Journal of the American Academy of Religion, 67(2), 327-354. https://doi.org/10.1093/jaarel/67.2.327

Bose, M., \& S. P. Bose (2013). A Woman's Ramayana: Candrāvat̄̄’s Bengali Epic

(Routledge Hindu Studies Series) (1st ed.). Routledge.

Bose, M., \& S. P. Bose (2004). The Ramayana Revisited. Oxford University Press. 
Re-Imagining Sita in Chitra Banerjee Divakaruni's The Forest of Enchantments: A Spiritual Ecofeminist Reading

Beauvoir, Simone de. (1984). After the Second Sex: Interviews with Simone de Beauvoir. New York: Pantheon Books.

Divakaruni, B. C. (2019). The Forest of Enchantments (1st ed.). HarperCollins India.

Gaard, G. (1998). Ecological Politics. Temple University Press.

MacGregor, S. (2004). From Care to Citizenship: Calling Ecofeminism Back to Politics.

Ethics \&amp; the Environment, 9(1), 56-84. https://doi.org/10.1353/een.2004.0007

Naidu, V. (2012). Sita's Ascent. Penguin Books.

Plumwood, V. (1996). Nature, Self, and Gender: Feminism, Environmental Philosophy, and the Critique of Rationalism. In K. J. W. Warren (Ed.), Ecological Feminist Philosophies (22nd ed., Vol. 1, pp. 8-13). Bloomington: Indiana University Press.

Rao, V. N. (2004). When Does Sita Cease to be Sita? : Notes Toward a Cultural Grammar of Indian Narratives. In M. Bose (Ed.), The Ramayana Revisited (pp. 219-241). New York: Oxford UP.

Richman, P. (2008). “Introduction: Whose Ramayana Is It?” Ramayana Stories in Modern South India: An Anthology (Paula Richman ed.). Indiana University Press.

Salleh, A. (1991). Staying Alive: Women, Ecology and Development. Vandana Shiva. London, Zed Books, 1989. Hypatia, 6(1), 206-214. https://doi.org/10.1111/j.15272001.1991.tb00218.x

Warren, K. J. (1993). A Philosophical Perspective on Ecofeminist Spiritualities. In C. Adams (Ed.), In Ecofeminism and the Sacred (pp. 125-135). New York: Continuum.

Warren, K. J. (2000). Ecofeminist Philosophy: A Western Perspective on What It Is and Why It Matters. New York: Rowman and Littlefield.

Warren, K. J., \& Cheney, J. (1991). Ecological Feminism and Ecosystem Ecology. Hypatia, 6(1), 179-197. https://doi.org/10.1111/j.1527-2001.1991.tb00216.x

\section{$\underline{\text { Bio-note }}$}

Gheeta Chandran obtained her degree in B.A (Hons) Literature in English (UKM) and M.A Postcolonial Literature in English (UKM). She is currently serving as a lecturer in the 
Department of Languages and Linguistics, Universiti Tunku Abdul Rahman, Perak. She is interested in Colonial and Postcolonial Literature, Diasporic Issues, Mythologies and Folklores and Malaysian Literature in English based research and projects.

Email: gheetac@utar.edu.my

Foong Soon Seng has obtained his PhD at the Faculty of Arts and Social Sciences, University of Malaya. He is currently the Deputy Dean (R \& D and Postgraduate Programmes) and an Assistant Professor in the Department of Languages and Linguistics, Universiti Tunku Abdul Rahman (Kampar Campus) Perak. His research interests include Feminist Writings (Women's Studies), Colonial \& Post-Colonial Literature, and Malaysian Literature in English.

Email: ssfoong@utar.edu.my

Raphael Thoo Yi Xian is a lecturer at the Department of Languages and Linguistics, Universiti Tunku Abdul Rahman. Currently pursuing a PhD in English Language, his research interests include critical discourse and literary analysis.

Email: thooyx@utar.edu.my 